\title{
Photo- and bioreactivity of chromophoric dissolved organic matter produced by marine bacterioplankton
}

\author{
Geraldine D. Kramer, Gerhard J. Herndl* \\ Department of Biological Oceanography, Royal Netherlands Institute for Sea Research (NIOZ), 1790 AB Den Burg, \\ The Netherlands
}

\begin{abstract}
The major source of oceanic dissolved organic matter (DOM) is organic compounds from phytoplankton released either directly during photosynthesis or via grazing. Bacterioplankton as a source of marine DOM have received considerably less attention. We determined the production of DOM during active bacterial growth in batch cultures with artificial seawater amended with glucose and inorganic nitrogen and phosphorus. During the initial growth of bacterioplankton, the fluorescence of bacterial-derived DOM increased steadily indicating release of chromophoric DOM. This bacterial-derived DOM was relatively rich in $\mathrm{N}$ and depleted in $\mathrm{P}$ as indicated by the C:N:P ratio of 147:29:1. Exposure of this bacterial-derived DOM to artificial solar radiation provoked a rapid decline in fluorescence indicating its photoreactivity. Re-growth experiments with natural bacterial assemblages inoculated into the solar radiation-exposed bacterial-derived DOM indicated that the bioavailability remained essentially unaltered, i.e. is refractory to bacterial utilization. Our findings indicate that bacterioplankton release chromophoric, refractory DOM during active growth and that this DOM, albeit being photoreactive does not stimulate bacterial growth activity upon exposure to solar radiation.
\end{abstract}

KEY WORDS: Bacterioplankton - Bacterial-derived DOM • UV radiation · Photoreactivity · Bioreactivity

Resale or republication not permitted without written consent of the publisher

\section{INTRODUCTION}

The pool of oceanic dissolved organic matter (DOM) represents, besides soil humus, the largest reservoir of organic matter of the biosphere (Hedges 1992). The major fraction of this oceanic DOM pool is derived from phytoplankton, either directly, via extracellular release (Obernosterer \& Herndl 1995, Teira at al. 2001, and references therein) or indirectly, through lysis and grazing (Bratbak et al. 1990, Lee \& Fisher 1994, Sherr \& Sherr 1994, Guixa-Boixareu et al. 1996).

Bacterioplankton as producers of marine DOM have received considerably less attention than phytoplankton. It has been shown, however, that bacteria produce copious amounts of largely refractory DOM (Brophy \& Carlson 1989, Tranvik 1993, Heissenberger \& Herndl 1994, Stoderegger \& Herndl 1998). Ogawa et al. (2001) showed in laboratory experiments that only $30 \%$ of the bacterial-derived DOM is hydrolyzable and, therefore, accessible for analysis on a molecular level.

Considerable information has accumulated over the past decade on the photochemical alteration and degradation of DOM. Photochemical degradation of DOM might enhance its overall availability for bacterioplankton (Lindell et al. 1995, Obernosterer et al. 1999). While this enhanced DOM bioreactivity upon exposure to solar radiation has been frequently reported (e.g. Kieber et al. 1989, Lindell et al. 1995, Obernosterer et al. 1999), DOM might also become less reactive upon exposure to solar radiation as compared to DOM held in the dark (Benner \& Biddana 1998, Obernosterer et al. 1999, 2001a). It has been suggested by Obernosterer et al. (1999) that originally more labile DOM becomes more refractory while originally more 
refractory DOM becomes more labile upon exposure to solar radiation. Overall, it has been estimated that about 2 to $4 \%$ of the oceanic DOC is photochemically oxidized to $\mathrm{CO}_{2}$ and CO per year (Moran \& Zepp 1997 , Obernosterer et al. 2001b).

In the present paper we tested the hypothesis that bacteria produce copious amounts of relatively refractory DOM from originally labile substrate during the exponential growth phase, and that this bacterialderived DOM is photoreactive and becomes more bioavailable for bacterial utilization upon exposure to solar radiation. Previous studies have already shown that bacteria produce refractory DOM (Brophy \& Carlson 1989, Tranvik 1993, Ogawa et al. 2001). Using short-term incubations of several days, Heissenberger \& Herndl (1994) showed that bacterioplankton release about $6 \%$ of the incorporated leucine as DOM larger than 50000 Da, while Stoderegger \& Herndl (1998) demonstrated that the capsular envelope of bacteria is constantly renewed, releasing the older material into the ambient water. These authors also showed that this bacterial-derived capsular DOM is semi-labile to refractory. Since a substantial part of the released DOM is chromophoric (Tranvik 1993, this study), we expected that exposure to solar radiation would substantially increase its bioavailability.

\section{MATERIALS AND METHODS}

Experimental approach to determine chromophoric DOM production by bacteria. The production of bacterial-derived chromophoric DOM was assessed in microcosm experiments. In total, 4 experiments each in duplicate were performed. Bacterioplankton of the coastal North Sea were collected from the NIOZ jetty at $0.5 \mathrm{~m}$ depth and immediately filtered through $0.8 \mu \mathrm{m}$ filters (polycarbonate, $140 \mathrm{~mm}$ filter diameter). This filtrate (5 l) was concentrated with a $0.2 \mu \mathrm{m}$ polycarbonate filter (Millipore, $47 \mathrm{~mm}$ ) and resuspended in artificial seawater. The concentrated $(\sim 20 \mathrm{ml})$ bacterial community was inoculated in 21 of $0.2 \mu \mathrm{m}$ filtered artificial seawater, amended with $200 \mu \mathrm{M}$ glucose-C, $20 \mu \mathrm{M} \mathrm{NH}_{4}{ }^{+}$, and $2 \mu \mathrm{M} \mathrm{PO}_{4}{ }^{3-}$. Bacteria were allowed to grow in the dark at $18^{\circ} \mathrm{C}$ for a period of 17 to $21 \mathrm{~d}$. Artificial seawater without bacteria inoculated served as an abiotic control. In these seawater batch cultures and in the control flasks bacterial abundance, dissolved organic carbon (DOC), nitrogen (DON), and phosphorus (DOP) concentrations, as well as DOM fluorescence were monitored at regular intervals as described below.

Experimental methods to evaluate the photoreactivity of bacterial-derived chromophoric DOM and its bioavailability. After allowing the bacterioplankton assemblage to grow for 17 to $21 \mathrm{~d}$ in nutrient amended artificial seawater, the bacteria were removed from the culture medium by filtering it twice through rinsed $0.2 \mu \mathrm{m}$ filters (Millipore, polycarbonate). Subsequently, the 21 filtrate was split. One half of the volume was exposed to artificial solar radiation in a quartz tube $(2.8 \mathrm{~cm}$ inner diameter) for up to $24 \mathrm{~h}$ and the other half was held in the dark by wrapping the borosilicate tube in aluminum foil. During this exposure, the DOM fluorescence was monitored at regular intervals.

Artificial solar radiation was provided by 3 different types of light sources. Two HQI-T Powerstar (Osram) lamps provided photosynthetic active radiation (400 to $700 \mathrm{~nm}$ wavelength range), 2 TL 100W/10R fluorescent light tubes (Philips) were used to provide UV-A (320 to $400 \mathrm{~nm}$ ) and 3 UVA-340 fluorescent light tubes (QPanel) supplied UV-A and UV-B (300-320 nm). The solar simulator was adjusted to $30-60 \%$ of the local maximum radiation intensity in late spring measured on a cloudless day (Pausz \& Herndl 2002). Thus, the dose rate received by the bacterial-derived DOM in our exposure experiments is similar to that expected in the top surface layer of the water column. To maintain in situ water temperature $\left(17\right.$ to $\left.18^{\circ} \mathrm{C}\right)$ during the exposure to artificial solar radiation, the treatments were kept in a flow-through water bath connected to a temperature control unit (LAUDA RCS/RC-6).

After exposing the bacterial-derived chromophoric DOM to artificial solar radiation, a natural bacterioplankton community (prepared as described above) was inoculated into the solar radiation-exposed and into the dark treatment and allowed to grow in the dark at $18^{\circ} \mathrm{C}$ for $2 \mathrm{~d}$. In order to check for growth limitation due to a lack of available $\mathrm{C}, \mathrm{N}$ or $\mathrm{P}$, different treatments were established enriched in these elements in 2 experiments (Expt II: unamended control, $200 \mu \mathrm{M}$ glucose-C, $20 \mu \mathrm{M} \mathrm{NH}_{4}{ }^{+}, 2 \mu \mathrm{M} \mathrm{PO}_{4}{ }^{3-}$; Expt III: unamended control, $5 \mu \mathrm{M} \mathrm{NH}_{4}{ }^{+}$and $1 \mu \mathrm{M} \mathrm{PO}_{4}{ }^{3-}$ ).

Enumeration of bacteria. To determine the bacterial abundance, 1 to $5 \mathrm{ml}$ of sample was fixed with $0.2 \mu \mathrm{m}$ filtered (Acrodiscs, Gelman) $37 \%$ formaldehyde $(4 \%$ final concentration), stained with 4',6-diamidino-2phenylindole-dihydrochloride (DAPI, final concentration $10 \mu \mathrm{g} \mathrm{ml}^{-1}$ ) and filtered onto a black $0.2 \mu \mathrm{m}$ polycarbonate filter (Millipore, $25 \mathrm{~mm}$ filter diameter) for counting under the epifluorescence microscopy (Zeiss Axioplan, 1250× magnification; Porter \& Feig 1980). Filters were stored in the dark at $-20^{\circ} \mathrm{C}$ until analysis (within 3 months after collection). At least 30 fields or 300 bacteria per sample were counted.

Analyses of DOM and inorganic nutrients. Samples for DOC, DON, DOP, and DOM fluorescence were filtered through combusted $\left(450^{\circ} \mathrm{C}\right.$ for $\left.4 \mathrm{~h}\right)$ Whatman GF/F glass fiber filters. For DOC determination, $8 \mathrm{ml}$ of 
the filtrate was transferred into combusted glass ampoules, immediately acidified with 3 to 4 drops of $45 \% \mathrm{H}_{3} \mathrm{PO}_{4}$ and then the ampoules were sealed. Samples were stored at $-20^{\circ} \mathrm{C}$ until analysis.

For the determination of the inorganic nutrients, DON and DOP, the samples were collected in acidrinsed polyethylene bottles and stored at $-20^{\circ} \mathrm{C}$ until analysis. All analyses were done within 3 mo of collecting the samples.

DOC analysis was performed on quadruplicate samples using the high temperature combustion method on a modified Shimadzu TOC-5000A. The absorbance of the $\mathrm{CO}_{2}$ evolving from the combusted DOC was detected with an external infrared cell (LiCor Model LI-6252) and quantified as peak area by the internal Shimadzu integrator. Ultra-pure $\mathrm{CO}_{2}$-free air was used as a carrier gas at a flow rate of $150 \mathrm{ml} \mathrm{min}^{-1}$. Samples were automatically injected with a Shimadzu ASI5000A autosampler on a platinized aluminum catalyst (Elemental Microanalysis) held at $680^{\circ} \mathrm{C}$ (Benner \& Strom 1993). Standards were prepared with potassium hydrogen phthalate (Baker) in Milli-Q water. The overall analytical precision was always better than $3 \%$.

DON and DOP analyses were performed simultaneously following the method of Valderrama (1981). This procedure is based on an alkaline persulphate digestion (at $120^{\circ} \mathrm{C}$ in an autoclave for $90 \mathrm{~min}$ ) over a wide $\mathrm{pH}$ range starting at $\mathrm{pH} 9$ and ending at $\mathrm{pH} 4$ using boric acid and sodium hydroxide. The resulting total nitrate and phosphate were measured using the autoanalyzer for inorganic nutrient determination as described below. The sum of the inorganic nitrogen species $\left(\mathrm{NH}_{4}{ }^{+}+\mathrm{NO}_{3}{ }^{-}+\mathrm{NO}_{2}{ }^{-}\right)$and phosphate concentrations were subtracted from the corresponding total dissolved $\mathrm{N}$ and $\mathrm{P}$ concentrations, respectively, to calculate the concentrations of DON and DOP. The recovery efficiency of DON and DOP was checked using a cocktail of 10 different compounds containing organic $\mathrm{N}$ and/or $\mathrm{P}$ measured in parallel with the samples. The recovery was $80 \%$ of the total added $\mathrm{N}$ in DON and $94 \%$ of the total added $\mathrm{P}$ in PON.

Concentrations of $\mathrm{NH}_{4}{ }^{+}, \mathrm{NO}_{2}{ }^{-}, \mathrm{NO}_{3}{ }^{-}$and $\mathrm{PO}_{4}{ }^{3-}$ were determined in a TRAACS autoanalyzer system. $\mathrm{NH}_{4}{ }^{+}$ was detected with the indo-phenolblue-method $(\mathrm{pH}$ 10.5) at $630 \mathrm{~nm}$ wavelength (Helder \& de Vries 1979). $\mathrm{NO}_{2}^{-}$was detected after diazotation with sulphanilamide and $N$ - (1-naphtyl)-ethylene diammoniumdichloride as the reddish purple dye complex at $540 \mathrm{~nm}$ (Parsons et al. 1984). $\mathrm{NO}_{3}{ }^{-}$was reduced in a copper cadmium coil to $\mathrm{NO}_{2}^{-}$(using imidazole as a buffer) and then measured as $\mathrm{NO}_{2}^{-}$. Phosphate was determined via the molybdenum blue complex at $880 \mathrm{~nm}$ according to Murphy \& Riley (1962).

For the determination of the DOM fluorescence, $3 \mathrm{ml}$ of the filtrate was immediately measured at an excita- tion of $350 \mathrm{~nm}$ and an emission wavelength of $450 \mathrm{~nm}$ using a $1 \mathrm{~cm}$ quartz cuvette in a Hitachi F-2000 fluorometer. The fluorescence was standardized with a quinine sulfate solution and is given in QSU (1 QSU = $1 \mathrm{ppb}$ quinine sulfate in $0.05 \mathrm{M} \mathrm{H}_{2} \mathrm{SO}_{4}$ ).

\section{RESULTS}

\section{Production of chromophoric DOM by marine bacterioplankton}

In the nutrient-amended artificial seawater batch cultures, bacterial abundance increased from initially $0.2 \times 10^{6}$ cells ml ${ }^{-1}$ to about $10 \times 10^{6}$ cells ml $^{-1}$ within $5 \mathrm{~d}$ (Fig. 1A). Thereafter, the natural bacterial community remained in the stationary phase for 3 to $5 \mathrm{~d}$ and sub-
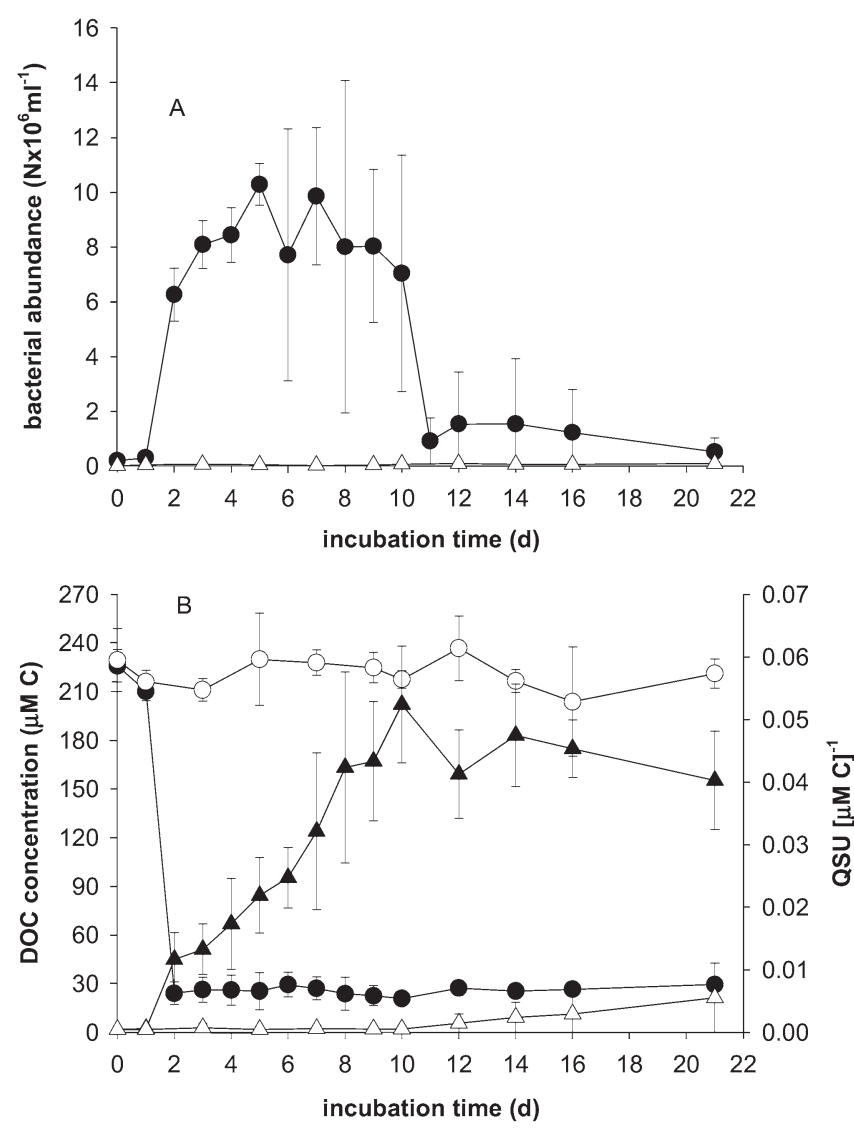

Fig. 1. Development of (A) the bacterial abundance and (B) the DOC concentrations and the DOC-normalized DOM fluorescence (in QSU $\left[\mu \mathrm{M} \mathrm{C}^{-1}\right.$ ) in the 4 batch culture experiments each done in duplicate with natural bacterial assemblages (solid symbols) and the corresponding control experiments where no bacteria were inoculated (open symbols). In (B), the DOC concentrations are indicated by circles and the DOC-normalized DOM fluorescence by triangles. The 3 data points for Days 14 to 21 of one of the abiotic control experiments were not included as bacterial growth was observed. Error bars indicate SD 
Table 1. Development of the concentrations of the dissolved organic carbon (DOC), nitrogen (DON), and phosphorus (DOP) (all in $\mu \mathrm{M}$ ) and the C:N, C:P and N:P ratios of the DOM in Expts II and III during the incubation of natural bacterial assemblages in batch cultures with artificial seawater amended with glucose and inorganic nutrients. The mean of duplicate incubations is given

\begin{tabular}{|lcccccc|}
\hline $\begin{array}{l}\text { Day of } \\
\text { incubation }\end{array}$ & $\begin{array}{c}\text { DOC } \\
(\mu \mathrm{M} \mathrm{C})\end{array}$ & $\begin{array}{c}\text { DON } \\
(\mu \mathrm{M})\end{array}$ & $\begin{array}{c}\text { DOP } \\
(\mu \mathrm{M})\end{array}$ & $\mathrm{C}: \mathrm{N}$ & $\mathrm{C}: \mathrm{P}$ & $\mathrm{N}: \mathrm{P}$ \\
\hline Expt II & & & & & & \\
0 & 167 & 4.8 & 0.2 & 38 & 851 & 25 \\
4 & 86 & 4.7 & 0.17 & 24 & 491 & 26 \\
9 & nd & 7.4 & 0.18 & nd & nd & 43 \\
17 & 46 & 7.3 & 0.29 & 6 & 168 & 27 \\
Expt III & & & & & & \\
0 & 212 & 3.8 & 0.03 & 66 & 6723 & 123 \\
5 & 25 & 7.4 & 0.16 & 4 & 159 & 47 \\
11 & 21 & 5.8 & 0.25 & 4 & 85 & 25 \\
20 & 27 & 6.5 & 0.22 & 5 & 127 & 31 \\
\hline
\end{tabular}

monitored as well in 2 duplicate experiments (Expts II and III) and are shown in Table 1. Over the course of the $21 \mathrm{~d}$ incubation period, the DON concentrations increased from about 4 to about $7 \mu \mathrm{M} \mathrm{N}$ in both experiments and DOP concentrations from 0.20 to $0.29 \mu \mathrm{M} P$ in Expt II and in Expt III from 0.03 to $0.22 \mu \mathrm{M} P$ (Table 1).

Generally, the C:N:P ratios of the bacterial-derived DOM pool remained remarkably stable over the course of the incubation period after the initial decrease from Day 0 to Day 4 due to the uptake of glucose (Table 1). At the end of the incubation, the $\mathrm{C}: \mathrm{N}$ ratio of the bacterial-derived DOM pool was 6 and 5 in Expts II and III, respectively. The C:P ratio of the DOM pool at the end of the experiments was 168 and 127 in Expts II and III,

sequently, bacterial abundance decreased rapidly to about 1 to $2 \times 10^{6}$ cells $\mathrm{ml}^{-1}$ (Fig. 1A). The bacterial abundance in the abiotic controls remained below $0.2 \times 10^{6}$ cells ml $^{-1}$ in all the experiments, except in one, where bacteria grew up in one of the duplicate flasks towards the end of this particular experiment (data not included in Fig. 1A).

Bacterioplankton were utilizing the $200 \mu \mathrm{M}$ glucose$\mathrm{C}$ added to the batch cultures within $2 \mathrm{~d}$ (Fig. 1B). On Day 2, the DOC concentrations were, on average, $24.1 \pm 6.9 \mu \mathrm{M} \mathrm{C}$ and varied subsequently between 20.8 and $29.5 \mu \mathrm{M} \mathrm{C}$. In the abiotic treatments without bacteria inoculation, the DOC concentrations remained stable over the entire incubation period (Fig. 1B), again with the exception of one experiment where bacterial growth was observed (data not included in Fig. 1B).

Concurrently with the sharp decline in DOC due to the uptake of the added glucose until Day 2, the DOCnormalized DOM fluorescence increased from undetectable levels on Day 0 to $0.012 \pm 0.004 \mathrm{QSU}[\mu \mathrm{M} \mathrm{C}]^{-1}$ on Day 2 (Fig. 1B). Subsequently, DOC-normalized fluorescence increased steadily until Day 9 when the highest DOM fluorescence was reached $0.052 \pm$ 0.009 QSU $\left[\mu \mathrm{M} \mathrm{C}^{-1}\right.$ ). Thereafter, the DOC-normalized DOM fluorescence decreased slightly and remained more or less constant thereafter until the end of the experiment (averaging $0.043 \pm 0.006 \mathrm{QSU}[\mu \mathrm{M} \mathrm{C}]^{-1}$ ) between Day 10 and Day 21. In the abiotic treatments, the DOC-normalized DOM fluorescence ranged from 0 to $0.001 \mathrm{QSU}[\mu \mathrm{M} \mathrm{C}]^{-1}$, again with the exception of one experiment where bacteria were growing up (data not included in Fig. 1B).

The dynamics of DON and DOP produced by bacterioplankton growing on inorganic $\mathrm{N}$ and $\mathrm{P}$ were respectively, and the N:P ratios were 27 and 31 in Expts II and III, respectively (Table 1).

\section{Photoreactivity of the bacterial-derived chromophoric DOM}

Exposure of the bacterioplankton-derived chromophoric DOM to solar radiation resulted in a rapid decline in the DOM fluorescence, while the DOM fluorescence in the dark treatments remained constant (Fig. 2). In Expt II, mean DOM fluorescence decreased from 0.069 to $0.020 \mathrm{QSU}[\mu \mathrm{M} \mathrm{C}]^{-1}$ within the initial $6 \mathrm{~h}$ of exposure to solar radiation. Thereafter, DOM fluorescence declined only slightly in Expt II reaching 0.016 QSU $[\mu \mathrm{M} \mathrm{C}]^{-1}$ at the end of the $24 \mathrm{~h}$ exposure period. In Expt III, however, DOM fluorescence decreased steadily throughout the entire exposure period reaching also a DOM fluorescence value of $0.016 \mathrm{QSU}[\mu \mathrm{M} \mathrm{C}]^{-1}$ after $11 \mathrm{~h}$ (Fig. 2). The decline in the DOC-normalized DOM fluorescence upon exposure to solar radiation indicates that bacterial-derived DOM is photoreactive although no significant decrease in DOC concentrations during the exposure to solar radiation was discernable (data not shown). The DOM fluorescence of the bacterial-derived DOM held in the dark remained essentially constant throughout the exposure period (Fig. 2).

\section{Utilization of bacterial-derived DOM by marine bacterioplankton}

Subsequent inoculation of natural bacterioplankton consortia with solar radiation-exposed bacterial- 


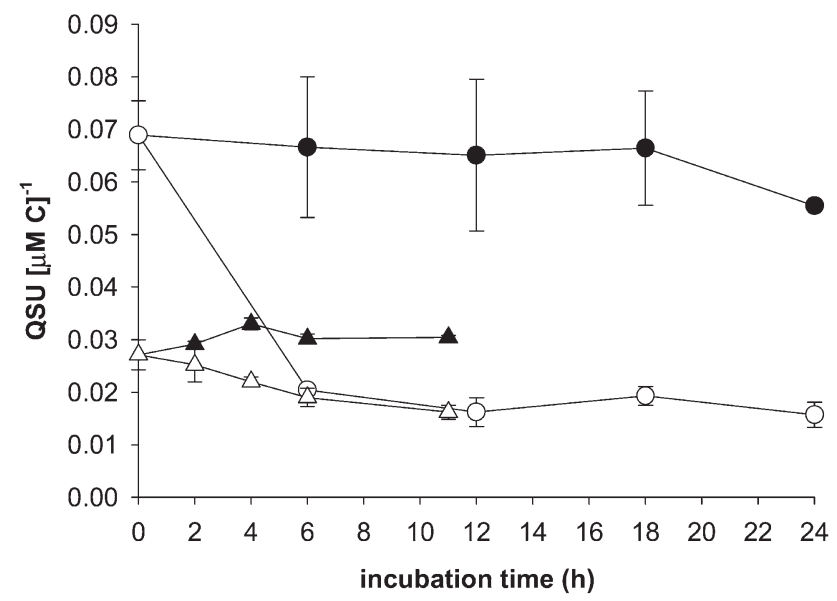

Fig. 2. Dynamics of the DOC-normalized DOM fluorescence during the exposure of bacterial-derived DOC to artificial solar radiation in Expts II (solid circles) and III (triangles). Open symbols represent solar radiation exposed and solid symbols DOM held in the dark. Symbols represent means

derived DOM and that held in the dark resulted in a maximum bacterial abundance not significantly different between the 2 treatments regardless whether additional $\mathrm{NH}_{4}{ }^{+}$and/or $\mathrm{PO}_{4}{ }^{3-}$ were added (Kruskal-Wallis, abundance data from 7 time points per treatment used for analysis, $p>0.05$ ) (Fig. 3). Only the addition of glucose-C in Expt II resulted in about twice the maximum bacterial abundance in both, the solar radiationexposed and the corresponding dark treatment (Fig. 3) indicating that the bioavailability of $\mathrm{C}$ was limiting bacterioplankton growth.

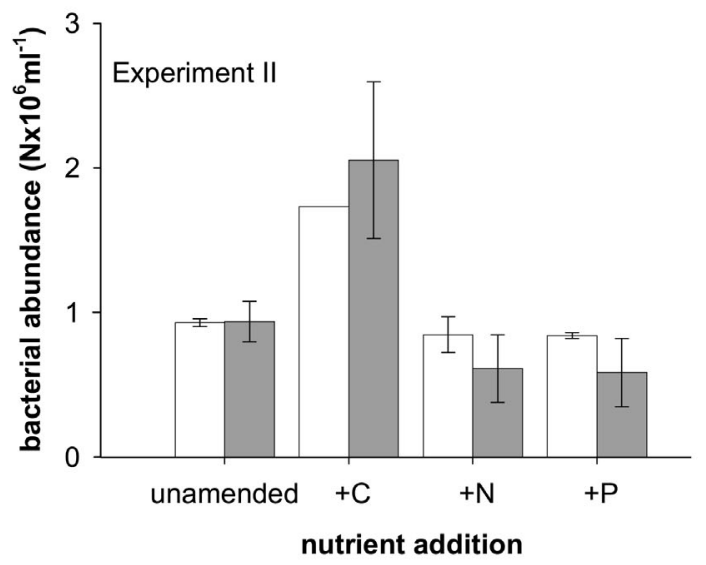
of duplicate treatments; vertical lines indicate the range

\section{DISCUSSION}

In the batch cultures with artificial seawater amended with nutrients, bacterioplankton were rapidly transforming labile organic matter (here in the form of glucose) into chromophoric DOM, as indicated by the steady increase of the DOM fluorescence in the treatments inoculated with a natural bacterial community (Fig. 1B). Correcting our DOC concentrations for the background DOC concentration of the artificial seawater ( $20 \mu \mathrm{M}$ DOC), bacterioplankton consumed essentially all the added glucose-C within $2 \mathrm{~d}$. Using a similar experimental approach, Ogawa et al. (2001) found that $85 \%$ of the added labile $\mathrm{C}$ was taken up by the bacteria within $2 \mathrm{~d}$. After $10 \mathrm{~d}$, DOC concentrations amounted to $9 \%$ of the initial concentration. Similarly, in the experiments of Ogawa et al. (2001), DOC concentrations decreased to $8 \%$ of the initial DOC after $7 \mathrm{~d}$.

DON derived from bacterioplankton increased in concentration during the course of the incubation by 52 and $70 \%$ in Expts II and III, respectively, representing a net production of 2.5 and $2.7 \mu \mathrm{M}$ DON, respectively (Table 1). The initial inorganic N concentrations (data not shown) decreased by $32 \%$ in Expt II and by $36 \%$ in Expt III, resulting in a net uptake of 7.5 and $8.8 \mu \mathrm{M} \mathrm{N}$, respectively, during the incubation. Thus, in our experiments, the bacterial community transformed a net percentage of around $30 \%$ of the inorganic $\mathrm{N}$ taken up into semilabile to refractory DON within 17 to 20 d. Heissenberger \& Herndl (1994) found that after $\sim 6 \mathrm{~d}, 60$ to $70 \%$ of the added ${ }^{14} \mathrm{C}$-leucine was transformed into high molecular weight DOM (>1000 Da).

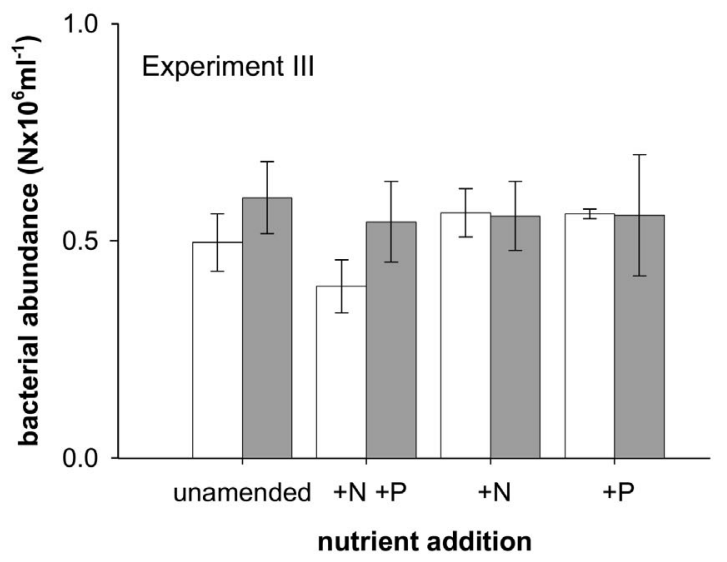

Fig. 3. Maximal bacterial abundance in the re-growth experiments after exposing bacterial-derived DOM to solar radiation or held in the dark and then inoculating a natural bacterial community after amending the bacterial derived DOM with different nutrients. The nutrient additions for Expt II were $200 \mu \mathrm{M}$ glucose-C $(+\mathrm{C}), 20 \mu \mathrm{M} \mathrm{NH}_{4}{ }^{+}(+\mathrm{N}), 2 \mu \mathrm{M} \mathrm{PO}_{4}{ }^{3-}(+\mathrm{P})$, and an unamended control (unamended); for Expt III the nutrient additions were $5 \mu \mathrm{M} \mathrm{NH}_{4}{ }^{+}$and $1 \mu \mathrm{M} \mathrm{PO}_{4}{ }^{3-}(+\mathrm{N}+\mathrm{P}), 5 \mu \mathrm{M} \mathrm{NH}_{4}{ }^{+}\left(+\mathrm{N}^{2}\right), 1 \mu \mathrm{M} \mathrm{PO}{ }_{4}{ }^{3-}$ $(+\mathrm{P})$, and an unamended control (unamended). White bars represent solar radiation exposed treatments; gray bars represent treatments held in the dark prior to inoculating bacteria. Average values and the range of duplicate experiments are given. Maximum bacterial abundance was reached after an incubation of 30 to $48 \mathrm{~h}$ 


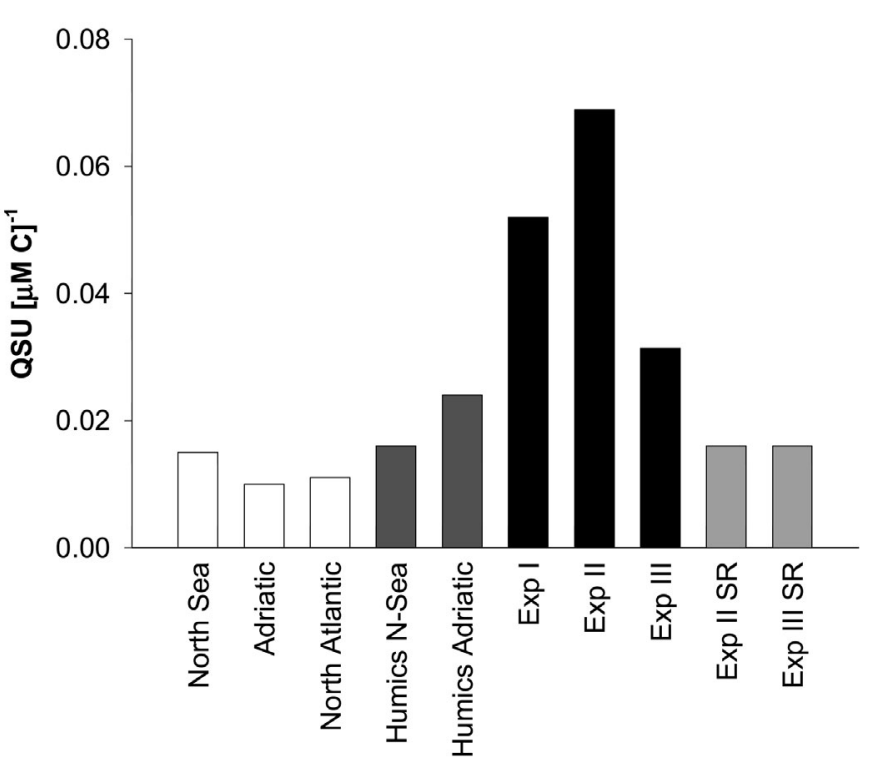

Fig. 4. Comparison of the DOC-normalized fluorescence of marine bulk DOM and its humic fraction obtained from the North Sea and the Adriatic with that of bacterial-derived DOM obtained in the present experiments. Expt II SR and Expt III SR are average values of duplicate treatments after the exposure to artificial solar radiation from Expts II and III. North Sea and Adriatic data are from Obernosterer \& Herndl (2000); North Atlantic data from Obernosterer et al. (2001b)

At the end of the incubation period of $10 \mathrm{~d}$, however, only $6 \%$ of the ${ }^{14} \mathrm{C}$-leucine was in the $>50000$ Da fraction of the DOM (Heissenberger \& Herndl 1994). Ogawa et al. (2001) measured bacterial-derived total hydrolyzable dissolved amino acid concentrations of 0.6 to $1.0 \mu \mathrm{M} \mathrm{N}$ representing only $\sim 30 \%$ of the total DON pool. Thus, taking this $30 \%$ recovery of DON into account, the bacterial-derived DON concentrations were 2 to $3 \mu \mathrm{M}$ DON, which is similar to the average DON concentration we determined $(2.6 \mu \mathrm{M})$.

After $20 \mathrm{~d}$ of incubation, the C:N:P ratio of the DOM produced by bacterioplankton was 168:27:1 in Expt II and 127:31:1 in Expt III. These C:N:P ratios of the bacterial-derived DOM are substantially lower than for bulk marine surface (C:N:P = 300:22:1, C:N = 17.8) and deep water DOM (C:N:P = 444:25:1, C:N = 13.6) compiled in Benner (2002). The low C:N ratios of 6 and 5 for Expts II and III, respectively, and the high N:P ratios indicate that bacterial-derived DOM is relatively rich in $\mathrm{N}$ but depleted in $\mathrm{P}$ as compared to the bulk oceanic DOM and the overall elemental composition of bacteria (Fagerbakke et al. 1996). This indicates that bacterioplankton are retaining $\mathrm{P}$ in the cell while releasing $\mathrm{N}$-rich compounds into the water. This also suggests that the viral lysis probably played only a minor role in releasing intracellular material into the ambient water since the P-content of the DOM would then reflect more closely the elemental composition of the bacterioplankton. Especially in the initial growth phase of bacteria in the batch culture (Days 4 to 5) viral lysis certainly played only a negligible role and because the bacterial-derived DOM already exhibited high C:P and N:P ratios (Table 1).

The fluorescence of the bacterial-derived DOM was up to 7 times higher than that of marine bulk DOM (Fig. 4) and at least twice as high as the fluorescence of the humic fraction of marine DOM extracted with XAD-8 resin (Obernosterer \& Herndl 2000) (Fig. 4). This comparison indicates that bacterial-derived DOM consists of highly chromophoric DOM. Chromophoric DOM has been shown to be highly photoreactive (Obernosterer \& Herndl 2000). Upon solar radiation cleavage products are formed from the parent humic substances which are efficiently utilized by bacterioplankton leading to an overall higher bioavailability of solar radiation-exposed humic substances (Obernosterer \& Herndl 2000). It has been shown that ammonia and amino acids are formed from N-containing humic matter upon exposure to solar radiation (Bushaw et al. 1996). Thus, we assumed that the N-rich bacterialderived DOM might become at least partially available to bacterioplankton utilization after exposure to solar radiation.

Upon exposure to artificial solar radiation, the fluorescence of the bacterial-derived DOM decreased during the initial $6 \mathrm{~h}$, thereafter, only small changes were detectable (Fig. 2). Although the initial DOC-normalized DOM fluorescence in Expt II was more than twice as high than the initial DOM fluorescence in Expt III, the final DOM fluorescence was similar in both experiments $\left(\sim 0.016\right.$ QSU $\left.[\mu \mathrm{M} \mathrm{C}]^{-1}\right)$. Thus, bacterial-derived DOM is photoreactive (Fig. 4). Bulk marine DOM is less photoreactive than bacterial-derived DOM since Obernosterer et al. (1999), exposing bulk marine DOM to similar radiation levels, report a decrease of DOCnormalized DOM fluorescence by $\sim 50$ and $22 \%$ for mesopelagic and surface waters of the Mediterranean Sea, respectively. For the coastal North Sea, the site from where the water used in this study originated, a decrease of DOC-normalized DOM fluorescence of only $17 \%$ was measured (see Table 2 in Obernosterer \& Herndl 2000). This is substantially lower than the decrease in fluorescence of bacterial-derived DOM upon exposure to solar radiation measured in this study (78 and $40 \%$, Fig. 4).

Re-growth experiments of bacterioplankton did not indicate enhanced bioavailability of solar radiationexposed bacterial-derived DOM (Fig. 3). Only in the carbon amended cultures could a significant growth of the bacterioplankton be observed independent of the exposure to solar radiation. Contrasting effects of solar radiation on the bioavailability of marine DOM have 
been previously reported (Benner \& Biddanda 1998, Obernosterer et al. 1999, 2001a). It was found that originally more labile DOM becomes more refractory upon solar radiation, while more refractory parent DOM becomes more labile (Obernosterer et al. 1999). Extrapolating these findings to our experiment, we would have expected a significant increase in the bioavailability of solar radiation-exposed bacterialderived DOM in the re-growth experiments. The lack of any significant changes in the bioavailability of bacterial-derived DOM upon solar radiation as compared to the DOM held in the dark indicates that either the production of growth stimulating and inhibiting photoproducts were balanced or, alternatively, the photoproducts formed were not accessible for the bacterial community. At present we cannot resolve the underlying processes leading to this lack in growth response of bacteria to solar radiation-exposed bacterial-derived DOM but similar observations have been made with bovine serum albumin exposed to solar radiation (Obernosterer et al. 1999).

In summary, we found that bacterioplankton are producing refractory DOM and that this DOM is photoreactive as indicated by the rapid loss in fluorescence upon exposure to solar radiation. This photoreactivity, however, does not lead to changes in the bioavailability of bacterial-derived DOM. Taken together, our findings indicate that bacterioplankton metabolism might be a significant source of refractory DOM in the ocean. The fate of this DOM in the oceanic water column, however, remains unclear.

Acknowledgements. The help of Karel Bakker with the DON and DOP analyses and the initial testing is gratefully acknowledged. Funding was provided by the Dutch Science Foundation (project 805.37.324 to G.J.H). This work is in partial fulfillment of the requirements for a $\mathrm{PhD}$ degree from the University of Groningen by G.D.K.

\section{LITERATURE CITED}

Benner R (2002) Chemical composition and reactivity. In: Hansell DA, Carlson CA (eds) Biogeochemistry of marine dissolved organic matter. Elsevier Science, New York, p 59-90

Benner R, Biddanda B (1998) Photochemical transformation of surface and deep marine dissolved organic matter: effects on bacterial growth. Limnol Oceanogr 43:1373-1378

Benner R, Strom RM (1993) A critical evaluation of the analytical blank associated with the DOC measurements by high-temperature catalytic oxidation. Mar Chem 41: 153-160

Bratbak G, Heldal M, Norland S, Thingstad TF (1990) Viruses as partners in spring bloom microbial trophodynamics. Appl Environ Microbiol 56:1400-1405

Brophy JE, Carlsson DJ (1989) Production of biologically refractory dissolved organic carbon by natural seawater microbial populations. Deep-Sea Res 36:497-507
Bushaw KL, Zepp RG, Tarr MA, Schulz-Jander D and 5 others (1996) Photochemical release of biologically available nitrogen from aquatic dissolved organic nitrogen. Nature 381:404-407

Fagerbakke KM, Heldal M, Norland S (1996) Content of carbon, nitrogen, oxygen, sulfur and phosphorus in native aquatic and cultured bacteria. Aquat Microb Ecol 10: $15-27$

Guixa-Boixareu N, Caldeerón-Paz JI, Heldal M, Bratbak G, Pedrós-Alió C (1996) Viral lysis and bacterivory as prokaryotic loss factors along a salinity gradient. Aquat Microb Ecol 11:215-227

Hedges JI (1992) Global biogeochemical cycles: progress and problems. Mar Chem 39:67-93

Heissenberger A, Herndl GJ (1994) Formation of high molecular weight material be free-living marine bacteria. Mar Ecol Prog Ser 111:129-135

Helder W, de Vries RTP (1979) An automatic phenolhydrochlorite method for the determination of ammonia in sea- and brackish waters. Neth J Sea Res 13:154-160

Kieber DJ, McDaniel J, Mopper K (1989) Photochemical source of biological substrates in sea water: implications for carbon cycling. Nature 341:637-639

Lee BG, Fisher NS (1994) Effects of sinking and zooplankton grazing on the release of elements from planktonic debris. Mar Ecol Prog Ser 110:271-281

Lindell MJ, Graneli W, Tranvik LJ (1995) Enhanced bacterial growth in response to photochemical transformation of dissolved organic matter. Limnol Oceanogr 40:195-199

Moran MA, Zepp RG (1997) Role of photoreactions in the formation of biologically labile compounds from dissolved organic matter. Limnol Oceanogr 43:1307-1316

Murphy J, Riley JP (1962) A modified single solution method for the determination of phosphate on natural waters. Anal Chim Acta 27:31-36

Obernosterer I, Herndl GJ (1995) Phytoplankton extracellular release and bacterial growth: dependence on the inorganic N:P ratio. Mar Ecol Prog Ser 116:247-257

Obernosterer I, Herndl GJ (2000) Differences in the optical and biological reactivity of the humic and non-humic dissolved organic carbon component in 2 contrasting coastal marine environments. Limnol Oceanogr 45:1120-1129

Obernosterer I, Reitner B, Herndl GJ (1999) Contrasting effects of the solar radiation on dissolved organic matter and its bioavailability to marine bacterioplankton. Limnol Oceanogr 44:1645-1654

Obernosterer I, Sempere R, Herndl GJ (2001a) Ultraviolet radiation induces reversal of the bioavailability of DOM to marine bacterioplankton. Aquat Microb Ecol 24:61-68

Obernosterer I, Ruardij P, Herndl GJ (2001b) Spatial and diurnal dynamics of dissolved organic matter (DOM) fluorescence and $\mathrm{H} 2 \mathrm{O} 2$ and the photochemical oxygen demand of surface water DOM across the subtropical Atlantic Ocean. Limnol Oceanogr 46:632-643

Ogawa H, Amagai Y, Koike I, Kaiser K, Benner R (2001) Production of refractory dissolved organic matter by bacteria. Science 292:917-919

Parsons T, Maita Y, Lalli C (1984) A manual of chemical and biological methods for seawater analysis. Pergamon Press, Oxford

Pausz C, Herndl GJ (2002) Role of nitrogen versus phosphorus availability on the effect of UV radiation on bacterioplankton and their recovery from previous UV stress. Aquat Microb Ecol 29:89-95

Porter KG, Feig YS (1980) The use of DAPI staining for identifying and counting aquatic microflora. Limnol Oceanogr 25:943-948 
Sherr EB, Sherr BF (1994) Bacterivory and herbivory: key roles of phagotrophic protists in pelagic food webs. Microb Ecol 28:223-235

Stoderegger K, Herndl GJ (1998) Production and release of bacterial capsular material and its subsequent utilization by marine bacterioplankton. Limnol Oceanogr 43:877-884

Teira E, Serret P, Fernandez E (2001) Phytoplankton sizestructure, particulate and dissolved organic carbon pro-

Editorial responsibility: Frede Thingstad, Bergen, Norway duction and oxygen fluxes through microbial communities in the NW Iberian coastal transition zone. Mar Ecol Prog Ser 219:65-83

Tranvik LJ (1993) Microbial transformation of labile dissolved organic matter into humic-like matter in seawater. FEMS Microbiol Ecol 12:177-183

Valderrama JC (1981) Simultaneous analysis of total nitrogen and phosphorus in natural waters. Mar Chem 10:109-122

Submitted: January 6, 2004; Accepted: June 28, 2004

Proofs received from author(s): August 16, 2004 